\title{
Chromate Transport in Human Leukocytes
}

\author{
David L. Litien, Jerry L. Spivak, and I. David Goldman \\ From the Human Tumor Cell Biology Branch and Laboratory of Molecular \\ Pharmacology, National Cancer Institute, National Institutes of Health, \\ Bethesda, Maryland 20014
}

A B S T R A C T Chromium is a trace metal of importance in human physiology and, in addition, as 51-chromate, has been extensively used as a label in the study of blood cell pool sizes and intravascular kinetics. The transport characteristics of 51-chromate were investigated in normal human leukocytes. Chromate uptake is unidirectional over a $1 \mathrm{hr}$ incubation with extracellular chromate concentrations up to $200 \mu$ moles/liter. Under these conditions, intracellular 51-chromium is in a form in which it is nonexchangeable. Influx is temperature sensitive with a $Q_{10}$ of approximately 2 and may be energy dependent since a variety of metabolic poisons strongly inhibit uptake. The unidirectional influx of chromate follows Michaelis-Menten kinetics; the maximum velocity is 52 m $\mu$ moles/g dry weight of cells per min and the chromate concentration at which influx velocity is half maximal is $87 \mu$ moles/liter. This transport mechanism is highly specific for chromate; other divalent tetrahedral anions only slightly inhibit influx at concentrations up to 10 times that of chromate. Metavanadate, however, competitively inhibits chromate influx at equimolar concentrations. Exposure of cells to unlabeled chromate leads to inhibition of subsequent influx of 51-chromate. It is suggested that this is due to a primary inhibitory effect of chromate on cellular energy metabolism.

\section{INTRODUCTION}

Radioactive chromium as sodium 51-chromate has been extensively used as a cell label since 1950 when Gray and Sterling (1) first reported its ability to bind to erythrocytes and utilized this interaction for estimation

Dr. Lilien's present address is the Department of Medicine, Los Angeles County-U. S. C. Medical Center, Los Angeles, Calif., 90033.

Dr. Spivak's present address is the Division of Hematology, Department of Medicine, Johns Hopkins University School of Medicine, Baltimore. Md.

Dr. Goldman's present address is the Department of Medicine, University of North Carolina School of Medicine, Chapel Hill, N. C., 27514.

Received for publication 10 June 1969 and in revised form 18 February 1970. of red cell mass. It was subsequently applied to studies of red cell intravascular kinetics (2) and has, in addition, been used to label tumor cells (3), platelets (4), and leukocytes (5) in similar types of studies. Apart from the importance of chromium in this regard, there is considerable evidence that it is an essential trace mineral in human physiology (6). Thus, an understanding of the mechanism by which chromium is transported across the cell membrane is of interest. As a part of investigations utilizing 51-chromate as a cell label, numerous attempts to define optimal labeling conditions have been made but there has been no systemic study of chromate uptake by cells. The present investigation was undertaken in an attempt to characterize in detail the mechanism by which chromate is taken up by human leukocytes.

\section{METHODS}

Cells. Normal human leukocytes were separated from citrated whole blood by centrifugation at $1500 \mathrm{~g}$ for $3 \mathrm{~min}$. To remove residual erythrocytes, the buffy coat was diluted $1: 1$ with $0.9 \% \mathrm{NaCl}$ and sedimented through a column of $3 \%$ dextran (average molecular weight of 280,000 ) followed by two $30-\mathrm{sec}$ periods of hypotonic lysis. The cells were washed in the incubation medium described below and then counted with an electronic counter (Model B, Coulter Electronics Inc., Hialeah, Fla.). All separation and preparation procedures were carried out at $4^{\circ} \mathrm{C}$ and cells were always used within $6-8 \mathrm{hr}$ of phlebotomy. The isolated cells consisted of from 55 to $70 \%$ polymorphonuclear leukocytes and from 30 to $45 \%$ lymphocytes. Contamination by other cell types was negligible.

Incubations. Methods of incubation and analytical techniques are slight modifications of those of Goldman, Lichtenstein, and Oliverio (7). Cells were suspended in a medium consisting of $124 \mathrm{mM} \mathrm{NaCl}, 5.3 \mathrm{~mm} \mathrm{KCl}, 1.1 \mathrm{~mm}$ $\mathrm{NaH}_{2} \mathrm{PO}_{4}, 16.0 \mathrm{~mm} \mathrm{NaHCO}_{3}, 1.9 \mathrm{~mm} \mathrm{CaCl}$, and $1 \mathrm{~mm}$ $\mathrm{MgCl}_{2}$ with $\mathrm{pH}$ adjusted to 7.4 after equilibration with $5 \%$ $\mathrm{CO}_{2}$. Cell densities ranged from 2.5 to $10 \times 10^{7}$ cells $/ \mathrm{ml}$. Incubations were carried out in a constant temperature bath with agitation or stirring and with the cell suspension in equilibrium with $95 \% \mathrm{O}_{2}-5 \% \mathrm{CO}_{2}$. Uptake was determined after addition of unlabeled $\mathrm{Na}_{2} \mathrm{CrO}_{4}$ with tracer amounts of $\mathrm{Na}_{2}{ }^{51} \mathrm{CrO}$ (Abbott Laboratories, North Chicago, Ill.) and with various test substances. Some cell clumping was encountered on occasion but did not significantly affect results. 
Analytical methods. Samples consisting of from 5 to $10 \times$ $10^{7}$ cells were obtained at appropriate times and immediately added to 10 volumes of $0.9 \% \mathrm{NaCl}$ at $0^{\circ} \mathrm{C}$. After centrifugation at $2000 \mathrm{~g}$ for $30 \mathrm{sec}$, the supernate was removed and discarded. The cells were then washed twice with $10-\mathrm{ml}$ aliquots of $0.9 \% \mathrm{NaCl}$ at $0^{\circ} \mathrm{C}$ by vigorous resuspension of the cell button followed by centrifugation as above. More than two washes did not result in the removal of additional 51-chromium from the cell fraction. The final supernate was removed as completely as possible and the cell button aspirated into the tip of a Pasteur pipet, transferred to preweighed glassine discs, and dried overnight at $65^{\circ} \mathrm{C}$. The dried cells on their glassine tares were then weighed and transferred to counting tubes. Dry weights varied from 3 to $6 \mathrm{mg}$. All weighings were done on a Cahn Electrobalance (Model RG, Cahn Instrument Co., Paramount, Calif.). Radioactivity was determined in a well-type scintillation counter (Nuclear-Chicago, Des Plaines, Ill.) with counting for a time sufficient to give a counting error of less than $\pm 1.4 \%$. Chromate uptake (as 51-chromium) was computed in millimicromoles per gram dry weight of cells, and velocity is expressed as uptake per minute. The error of measurement is expressed as \pm 1 SD. All straight lines were derived by the method of least squares; statistical significance was determined by the use of Student's $t$ test.

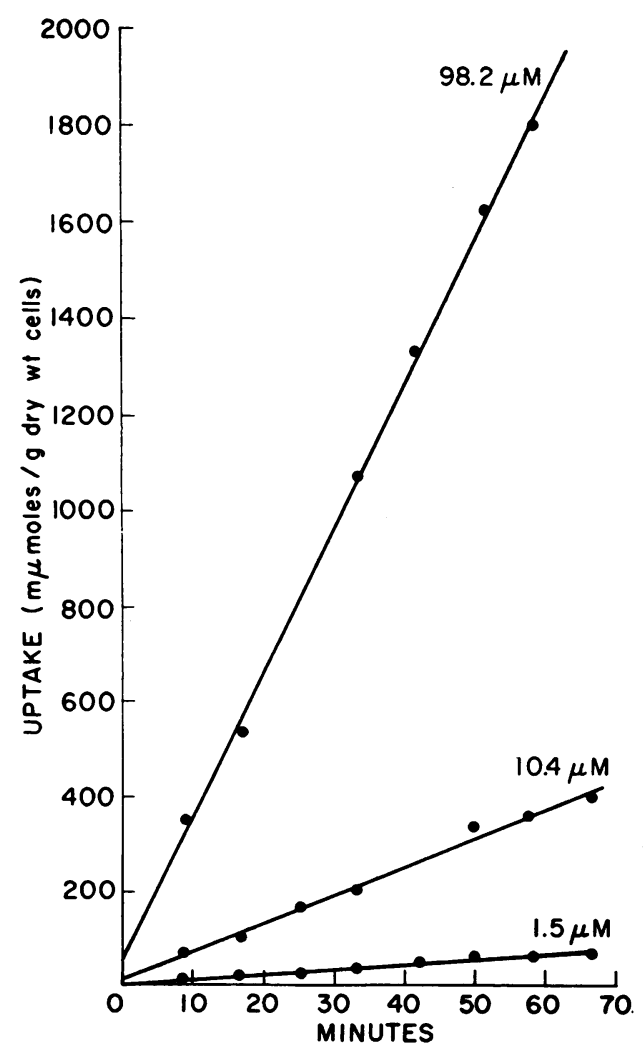

Figure 1 Time course of chromate uptake. Uptakes at the indicated extracellular chromate concentrations are from a single experiment.

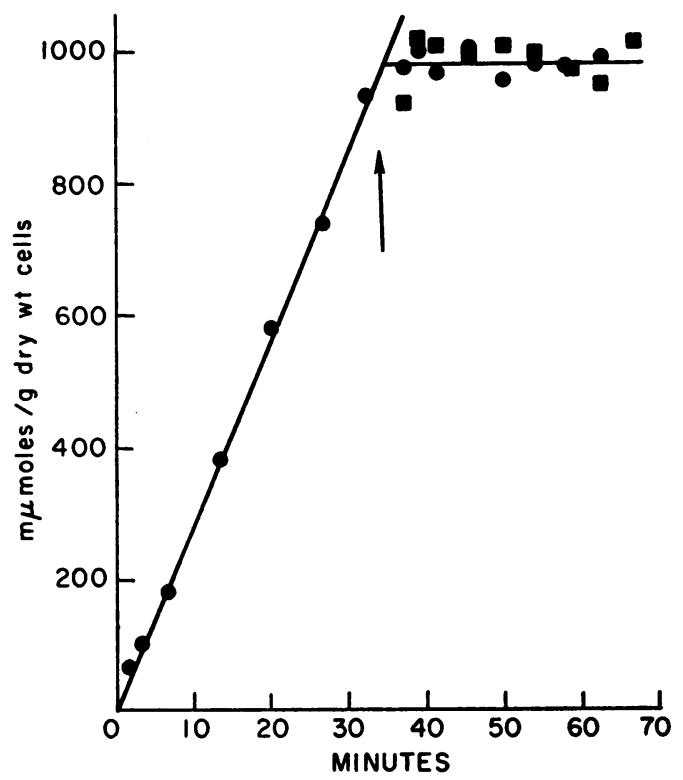

FIGURE 2 Nonexchangeability of intracellular chromium. Cells were incubated with $80 \mu \mathrm{M}$ 51-chromate for $33 \mathrm{~min}$, then rapidly separated from the medium by centrifugation and resuspended (at the time indicated by the arrow) into large volumes of chromate-free medium ( $\bullet$ ), or medium containing $160 \mu \mathrm{M}$ unlabeled chromate $(\boldsymbol{\omega})$.

\section{RESULTS}

Time course of chromate uptake. Chromate uptake was found to be linear for at least 65 min over an extracellular concentration range of 0.1-200 $\mu$ moles/liter. A typical experiment is shown in Fig. 1. In all experiments a positive ordinate intercept was found when the line of best fit was extrapolated back to zero time. Thus, there appears to be an early rapid association of chromate with the cells which was found to be essentially complete within $15 \mathrm{sec}$ after addition of chromate to the incubation medium.

Effect of temperature on chromate uptake. The time course of uptake was studied over a range of temperatures from $0^{\circ}$ to $37^{\circ} \mathrm{C}$. At $0^{\circ}$, the uptake rate was less than $10 \%$ of the rate at $37^{\circ}$. The ordinate intercept was still present at $0^{\circ}$; however, a possible relationship between temperature and intercept was not evaluated. Calculated $Q_{10}$ values were 2.0 for the intervals $27^{\circ}$ $37^{\circ} \mathrm{C}$ and 2.2 for the interval $17^{\circ}$ to $27^{\circ} \mathrm{C}$.

Exchangeability of intracellular chromium. Cells incubated with 51-chromate were separated from the medium by centrifugation and resuspended in a large volume of medium without 51-chromate (Fig. 2). Under these conditions there was no loss of 51-chromium from the cells. Intracellular chromium does not exist in a form readily exchangeable with nonlabeled hexavalent chromium since addition of this ion to the resuspension 


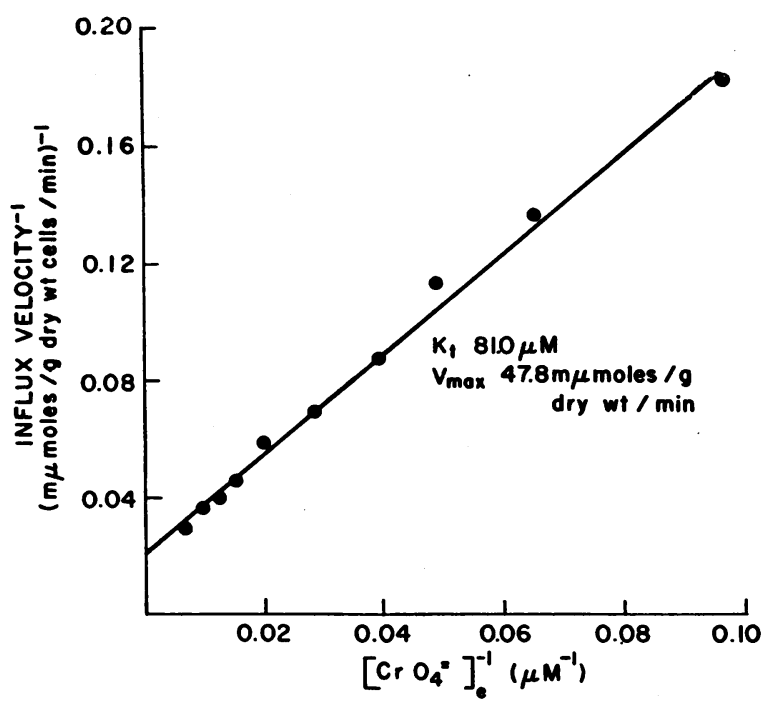

FIgURE 3 Kinetics of chromate influx. The reciprocal relationship between unidirectional chromate influx velocity and extracellular chromate concentration $\left(\left[\mathrm{CrO}_{4}\right]_{0}\right)$ is shown. To eliminate the early rapid uptake component, the influx rate was calculated from the rise in cell chromate between 200 and $2000 \mathrm{sec}$.

medium (Fig. 2) did not result in net loss of 51chromium.

Kinetics of chromate influx. The linearity of the time course of chromate uptake and the lack of exchangeable intracellular chromium indicate that net chromate uptake is a measure of its unidirectional influx velocity. The relationship between influx velocity and extracellular chromate concentration was quantitated. The rate of chromate influx was measured between 200 and 2000 sec to exclude the contribution of the early-rapid uptake component. During this time interval and over a range of extracellular chromate of from 1 to $200 \mu$ moles/liter, changes in the extracellular concentration due to cellular uptake were not significant and chromate uptake was linear with time.

The results of a typical single experiment are shown in Fig. 3. The linearity of the double reciprocal plot with a positive ordinate intercept suggests that chromate influx is compatible with Michaelis-Menten kinetics. In 12 experiments, the maximum influx velocity ( $\left.V_{\max }\right)$ was $51.9 \pm 9.6 \mathrm{~m} \mu \mathrm{moles} / \mathrm{g}$ dry wt per min, and the chromate concentration at which influx velocity was $\frac{1}{2} V_{\max }$ $\left(\mathrm{K}_{\mathrm{t}}\right)$ was $87.1 \pm 11.7 \mu \mathrm{moles} / \mathrm{liter}$.

Since the chromate concentrations are so much higher than reported normal human blood chromium values of from 0.5 to $1.0 \mu$ moles/liter (6), we were concerned that a higher-affinity, lower-capacity transport system might have been overlooked. That such a mechanism could be significant is unlikely since chromate influx velocity is a linear function of the extracellular chromate concentration over a range of from 0.1 to $8 \mu$ moles/ liter (Fig. 4) and the intercept of this plot passes through the origin.

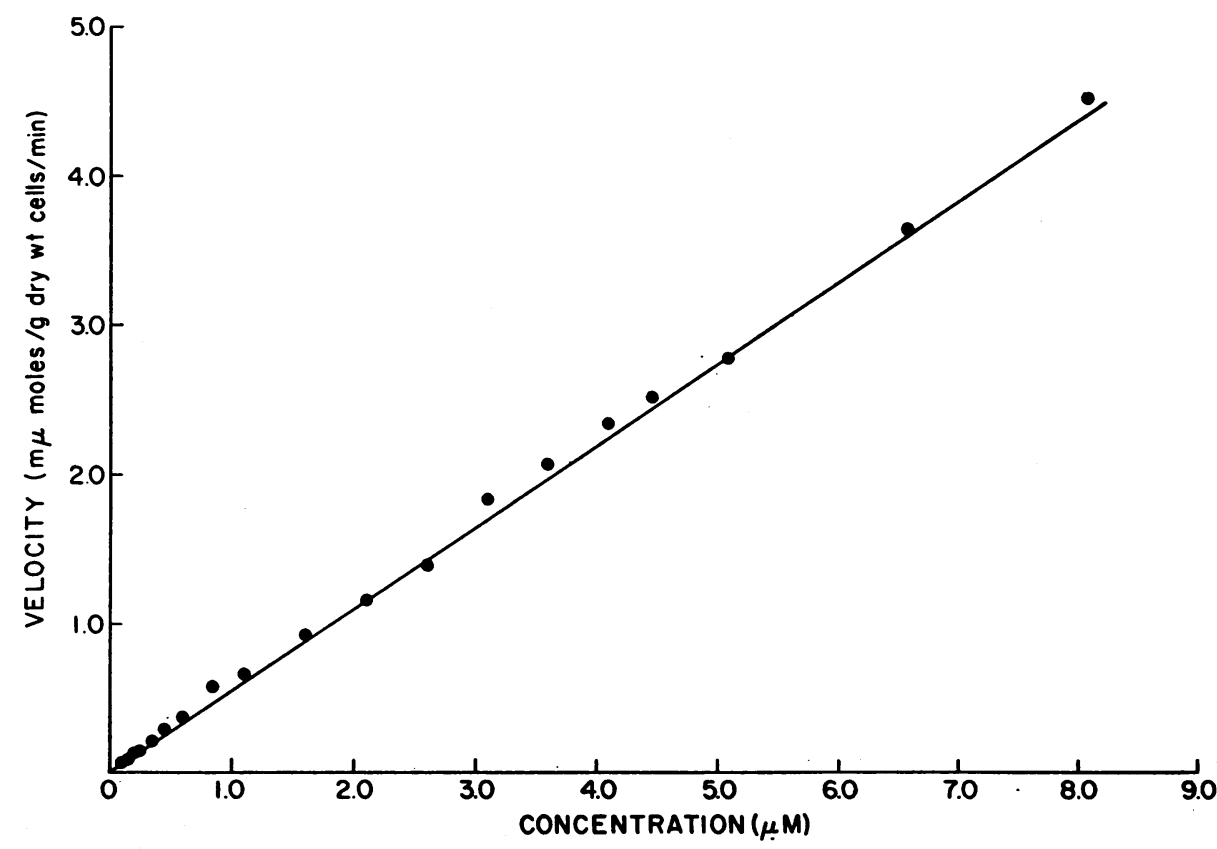

FIGURE 4 The relationship between low extracellular chromate concentrations and unidirectional influx velocity. Influx was measured as described in the text and the legend in Fig. 3. 
TABLE I

Effect of Various Anions on Chromate Transport by Human Leukocytes

\begin{tabular}{lcccc}
\hline \multicolumn{1}{c}{ Compound } & $\begin{array}{c}\text { Concen- } \\
\text { tration }\end{array}$ & $\begin{array}{c}\text { Uptake } \\
\text { velocity } \\
( \pm 1 \text { SD })\end{array}$ & $\begin{array}{c}\text { Inhibi- } \\
\text { tion }\end{array}$ & $P$ \\
\hline & $\mu$ moles $/$ liter & & $\%$ & \\
Control & - & $26.46 \pm 0.76$ & - & - \\
$\begin{array}{l}\text { Control without } \\
\text { phosphate }\end{array}$ & - & $24.66 \pm 0.44$ & 6.8 & $<0.025$ \\
Sodium sulfate & 750 & $22.78 \pm 0.70$ & 13.9 & $<0.005$ \\
& 75 & $25.54 \pm 0.54$ & 3.5 & $>0.1$ \\
Sodium tungstate & 750 & $22.45 \pm 0.40$ & 15.1 & $<0.005$ \\
& 75 & $25.87 \pm 0.37$ & 2.2 & $>0.2$ \\
Sodium molybdate & 750 & $20.23 \pm 0.48$ & 23.5 & $<0.001$ \\
& 75 & $25.13 \pm 0.51$ & 5.0 & $>0.05$ \\
Sodium metavanadate & 75 & $23.51 \pm 0.47$ & 11.1 & $<0.01$ \\
\hline
\end{tabular}

Data from a single experiment with determinations in triplicate. Uptake of $75 \mu \mathrm{M}$ 51-chromate over $35 \mathrm{~min}$ was measured in the presence of the above anions. Velocity is expressed as $\mathrm{m} \mu \mathrm{moles} / \mathrm{g}$ dry wt per $\mathrm{min}$.

In these experiments, the magnitude of the rapid uptake component was found to be proportional to the extracellular chromate concentration up to a level of at least $150 \mu$ moles/liters.

Effect of various anions on chromate influx. All anions studied caused significant inhibition of chromate influx velocity (Table I); only metavanadate, however, caused inhibition at concentrations equimolar with chromate. The time course of uptake in the presence of metavanadate was linear, indicating that under these condi-

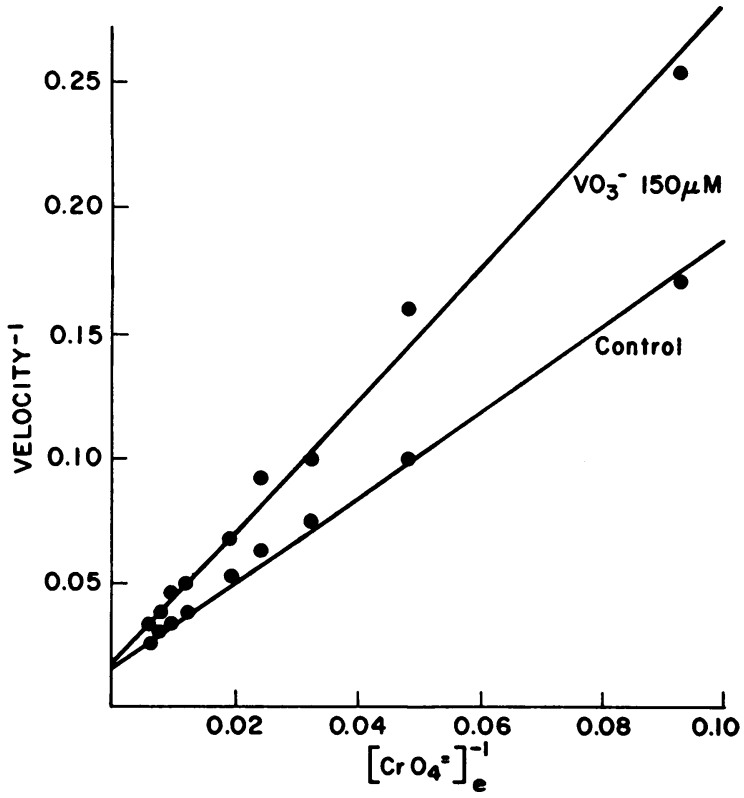

FIGURE 5 Kinetics of chromate influx in the presence and absence of $150 \mu \mathrm{M}$ metavanadate $\left(\mathrm{VO}_{8}^{-}\right)$. tions chromate flux remains unidirectional. The effect of $150 \mu \mathrm{M}$ metavanadate on the kinetics of chromate influx is seen in Fig. 5. In the presence of metavanadate the slope of the reciprocal plot is increased while the ordinate intercept is unchanged, indicating competitive inhibition.

Results with phosphate-free buffer indicate that $1.1 \mathrm{~mm}$ phosphate present in the usual medium does not inhibit chromate influx; on the contrary, the presence of phosphate appears to cause a small $(6.8 \%)$ but significant rise in chromate influx possibly due to an enhancement of energy metabolism (see below).

Effect of metabolic inhibitors on chromate influx. The effects of a variety of metabolic inhibitors on chromate transport are listed in Table II. All caused significant depression of chromate influx. Again, the time course of uptake in the presence of these inhibitors remained linear. Inhibition by 2,4-dinitrophenol was reversed by the addition of glucose, while glucose alone did not alter chromate influx. From other experiments, $0.1 \mathrm{mM}$ sodium $p$-chloromercuribenzene sulfonate inhibited chromate influx by $57.3 \%$

The effect of iodoacetate and 2-deoxyglucose on the kinetics of chromate influx was studied. In four experiments, both inhibitors caused depression of the influx $V_{\max }$ with a smaller rise in the influx $\mathrm{K}_{\mathrm{t}}$. A typical experiment is shown in Fig. 6. Although these kinetic alterations were not quantitatively prominent, they were seen in all experiments.

Self-inhibition of chromate influx by chromate. To investigate the possibility of a carrier mechanism for

TABLE II

Effect of Metabolic Inhibitors on Chromate Transport by Human Leukocytes

\begin{tabular}{lccc}
\hline \multicolumn{1}{c}{ Inhibitor } & $\begin{array}{c}\text { Concen- } \\
\text { tration }\end{array}$ & $\begin{array}{c}\text { Uptake } \\
\text { velocity } \\
( \pm 1 \mathrm{SD})\end{array}$ & $\begin{array}{c}\text { Inhibi- } \\
\text { tion }\end{array}$ \\
\hline & mmoles/liter & & $\%$ \\
Control & - & $4.66 \pm 0.09$ & - \\
Control + glucose, $1 \mathrm{mg} / \mathrm{ml}$ & - & $4.71 \pm 0.25$ & - \\
2,4-Dinitrophenol & 0.1 & $4.12 \pm 0.10$ & 11.5 \\
2,4-Dinitrophenol + glucose, & & & \\
$\quad 1 \mathrm{mg} / \mathrm{ml}$ & 0.1 & $4.76 \pm 0.12$ & 0 \\
Sodium azide & 10 & $3.96 \pm 0.04$ & 15.0 \\
Sodium iodoacetate & 1 & $3.26 \pm 0.17$ & 29.9 \\
2-Deoxy- $d$-glucose & 5 & $3.22 \pm 0.04$ & 30.9 \\
Sodium arsenite & 10 & $1.26 \pm 0.06$ & $\mathbf{7 3 . 0}$ \\
\hline
\end{tabular}

Date from a single experiment with quadruplicate determinations. Cells were incubated with $8.5 \mu \mathrm{M}$ 51-chromate for $35 \mathrm{~min}$ in the presence of the listed inhibitors. Velocity is expressed as $\mathrm{m} \mu \mathrm{moles} / \mathrm{g}$ dry wt per min. The differences between control velocity with and without glucose and between control and dinitrophenol + glucose are not significant $(P>0.5)$. For differences between control and all other values $P<0.001$. 
chromate transport, attempts were made to demonstrate exchange diffusion by measuring the initial chromate influx velocity into cells preloaded with structural analogs previously shown to inhibit chromate influx when present in the extracellular compartment (see Table I). In these experiments no significant effect was found with any of the compounds studied. Unexpectedly however, influx of labeled chromate was found to be inhibited in cells preincubated with unlabeled chromate. Inhibition was not significant at preincubation concentrations below $5 \mu$ moles/liter, but increased with the extracellular concentration up to at least $75 \mu$ moles/liter. The time course of chromate uptake in control cells and in cells preincubated with chromate or metavanadate is seen in Fig. 7. Cells were preincubated with $150 \mu$ moles/ liter of unlabeled chromate or metavanadate while the labeled chromate concentration for subsequent uptake ( $5 \mu \mathrm{moles} / \mathrm{liter}$ ) was low enough not to itself significantly affect chromate uptake. Metavanadate was without effect, but chromate preincubation decreased subsequent 51 -chromate influx velocity by $15.2 \%$. The linearity of uptake between 1 and $15 \mathrm{~min}$ in the chromate preincubated cells indicates that the inhibition is constant and irreversible over this interval. While it is possible that partial reversal of the inhibition could occur within 1 min after resuspension of cells in the medium containing low chromate concentrations, this would result in a downward displacement of the ordinate intercept for the chromate-preincubated cells, which did not occur.

It is apparent that chromate "autoinhibition" must occur instantaneously since from other experiments the

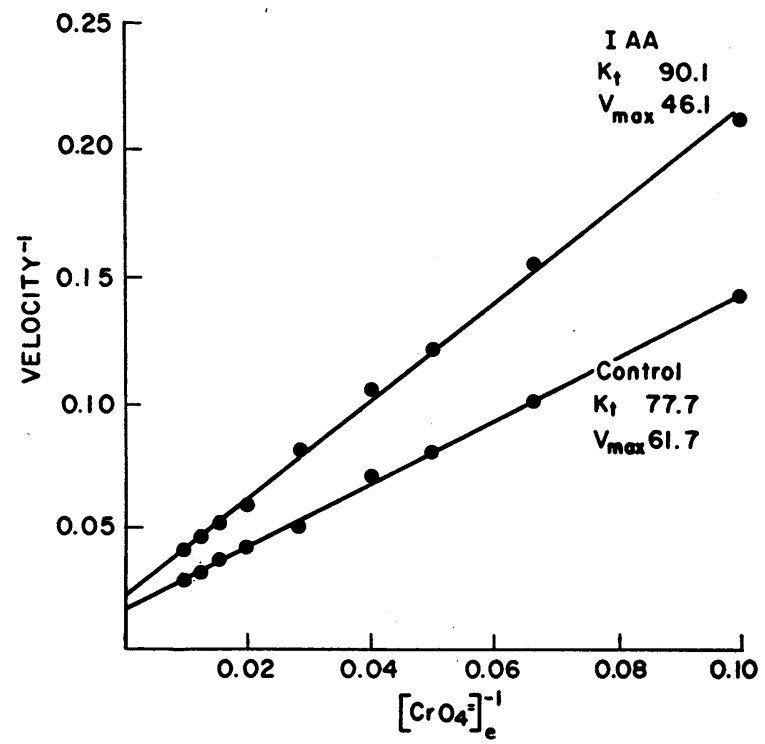

Figure 6 Kinetics of chromate influx in the presence and absence of $1 \mathrm{mM}$ iodoacetate (IAA). $\mathrm{K}_{\mathrm{t}}$ is expressed as $\mu \mathrm{M}$ and $V_{\max }$ as $\mathrm{m} \mu \mathrm{moles} / \mathrm{g}$ dry wt per $\mathrm{min}$.

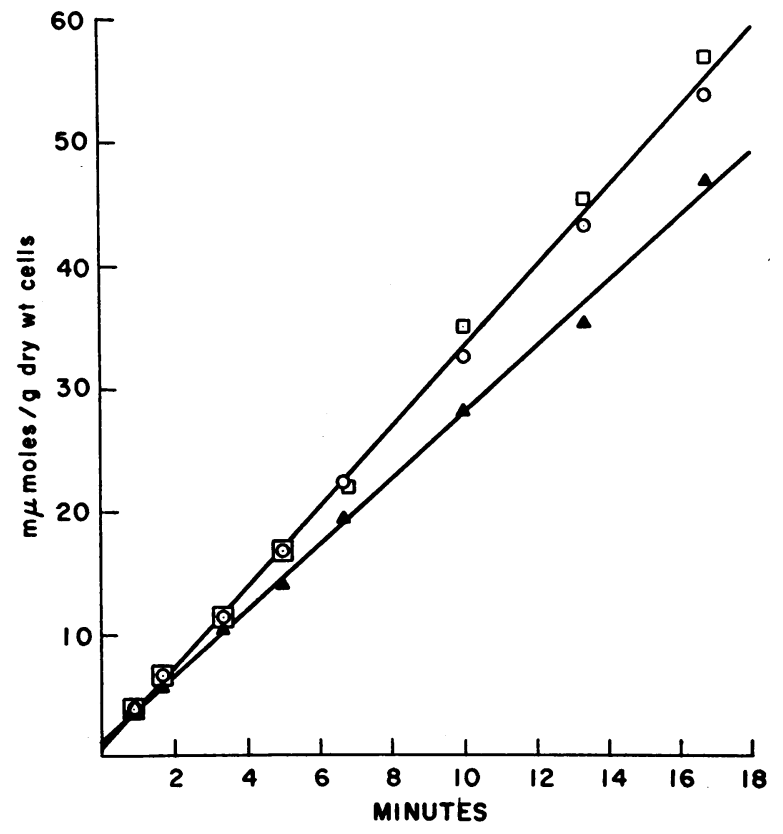

FIGURE 7 Time course of chromate uptake after preincubation with chromate and vanadate. Uptake in control cells (O) is compared with cells preincubated for $30 \mathrm{~min}$ with $150 \mu \mathrm{M}$ unlabeled chromate $(\Delta)$ or $150 \mu \mathrm{M}$ vanadate $(\square)$. After preincubation, cells were washed twice with $0^{\circ} \mathrm{C}$ medium and resuspended with fresh medium containing $5 \mu \mathrm{M}$ 51-chromate.

time course of chromate influx is linear within $15 \mathrm{sec}$ after the addition of inhibitory concentrations of 51 chromate to the incubation medium. This was confirmed by an experiment in which it was found that preincubation with unlabeled chromate for as little as $25 \mathrm{sec}$ caused maximum inhibition of subsequent 51-chromate influx.

It was important to demonstrate that the observed chromate influx kinetics were due to saturation of the transport mechanism rather than to a concentrationdependent autoinhibition by chromate. To evaluate this possibility, experiments were done to minimize the effects of chromate "autoinhibition" on chromate unidirectional influx kinetics. Cells were preincubated with $150 \mu$ moles/liter of unlabeled chromate after which the 51-chromate influx velocity was measured over a range of concentrations below that used in the preincubation. This procedure was designed to give maximum inhibition during preincubation so that subsequent incubations at lower chromate levels would not cause additional inhibition. Under these conditions influx continues to follow Michaelis-Menten kinetics (Fig. 8). The kinetic changes produced by chromate preincubation are difficult to evaluate since the inhibition is small and experimental scatter was consistently greater in this type of experiment than in others.

Chromate Transport in Human Leukocytes 


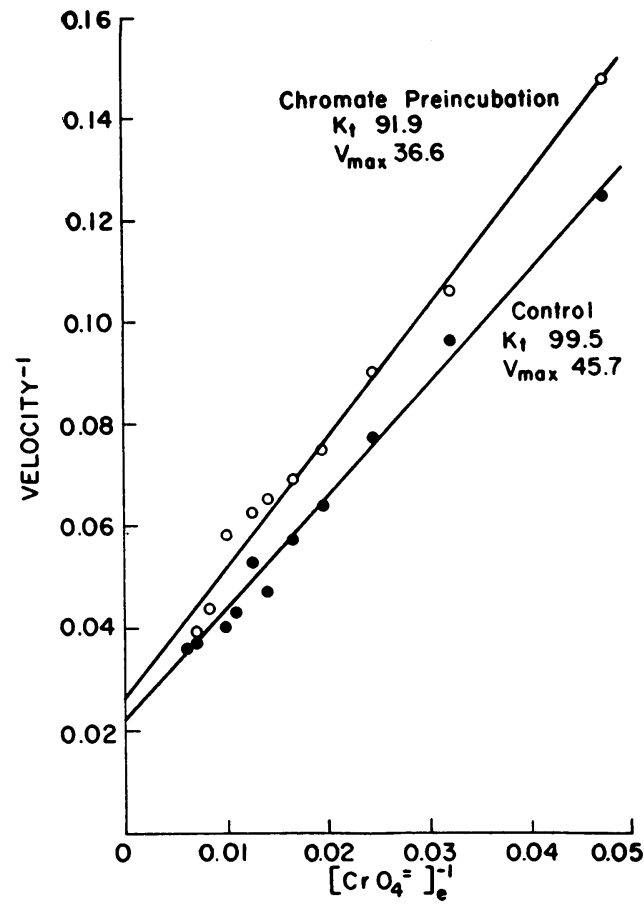

FigURE 8 Kinetics of chromate influx in control cells and cells preincubated with chromate. Cells were preincubated with $150 \mu \mathrm{M}$ unlabeled chromate for $30 \mathrm{~min}$, washed twice with $0^{\circ} \mathrm{C}$ medium, and resuspended with fresh medium containing 51-chromate. Kinetic parameters are expressed in the same units as in Fig. 6.

\section{DISCUSSION}

These studies establish the existence of a transport mechanism for chromate ion in the human leukocyte. Chromate influx follows Michaelis-Menten kinetics and the influx $Q_{10}$ is compatible with a mediated process. This mechanism is highly specific since related anions only weakly inhibit chromate influx even at very high concentrations. Only metavanadate inhibited chromate influx at equimolar concentrations and the kinetics of this inhibition were competitive.

Evidence that chromate transport is uphill against an electrochemical-potential gradient was not obtainable since conditions were never achieved under which significant free intracellular chromate could be demonstrated. However, the data suggests that the transport process may be energy dependent since influx was inhibited by a variety of metabolic poisons. In the absence of exchangeable intracellular chromate, it was also difficult to test for a possible carrier mechanism by exchange phenomena. While the unidirectional influx of chromate into cells preincubated with metavanadate was unchanged, the degree to which metavanadate enters the cell, if at all, and its intracellular fate are not known.

These studies indicate that the intracellular disposition for chromate involves reaction(s) that render it incapable of readily leaving the cell or of exchanging with extracellular unlabeled chromate. Because free intracellular chromate does not accumulate, these reaction(s) must proceed as fast as chromate enters the cell and thus the influx process is unidirectional, uptake is linear with time, and influx is the rate-limiting step in the association of 51-chromate with these cells. In addition, since this linear relationship is maintained under a number of inhibitory conditions such as in the presence of metabolic poisons or metavanadate, or after exposure to unlabeled chromate, these inhibitory effects must be due to a direct effect on the transport process itself or its energetics rather than to an effect on the intracellular disposition of chromate.

The lack of exchangeable intracellular chromate in this study is compatible with other reported data. Most intracellular chromium in erythrocytes incubated with 51 -chromate is protein bound, largely to the $\beta$-chain of the globin moiety of hemoglobin (8). There is evidence that hexavalent chromate ( $\mathrm{Cr}$ VI) is reduced to the trivalent state ( $\mathrm{Cr}$ III) before, or during the binding to hemoglobin (9), and after uptake into Ehrlich ascites cells (10) and leukocytes (11). Cr III does not exist in biological systems in a simple cationic form but rather as coordination compounds with substituent groups of low molecular weight compounds, such as glutathione, or larger molecules, such as proteins $(6,12)$. These chromium coordination compounds have a slow rate of ligand exchange and the complexes are quite stable (6).

The inhibitory effect of chromate preincubation on subsequent 51-chromate influx is interpreted as reflecting a primary inhibition of energy metabolism by chromate which in turn affects the energy-dependent transport of that ion. In the absence of exchangeable intracellular chromate, this cannot be related to an exchange phenomenon. The rapidity of onset of the chromate "autoinhibition," the observation that uptake is linear with time, and the dependence of the inhibitory effect on extracellular chromate concentration rather than on the total amount of chromium within the cell suggests that this action of chromate on the metabolic apparatus is at sites on or near to the cell surface. This would be consistent with an effect on the site of energy coupling with transport but the lack of a suitable model for chromate transport does not allow for precise localization.

The mechanism of chromate "autoinhibition" is likely related to the ability of chromate to inhibit energy metabolism. Thus $200 \mu_{\mathrm{M}}$ chromate inhibits red blood cell oxygen consumption (13); and in preliminary studies in this laboratory with human leukocytes, $35 \mu_{\mathrm{M}}$ chromate decreased base line oxygen consumption while $20 \mu \mathrm{M}$ chromate abolished the increment in oxygen con- 
sumption associated with the phagocytosis of latex particles. This effect may be related to inhibition of enzymes in the energetic pathways; chromium inhibits erythrocyte glutathione reductase (14) and has been isolated in erythrocyte fractions which contain a number of other important enzymes including glucose-6. phosphate dehydrogenase (12).

Although the measured portion of the time course of chromate uptake is linear, there is an early rapid uptake component which occurs instantaneously and persists at $0^{\circ} \mathrm{C}$. This probably represents a surface adsorption of 51-chromium to the cell membrane. It is also possible that this component represents a burst of chromate influx before autoinhibition becomes significant. To account for this, however, the uninhibited rate would have to be far greater than seems likely with the degree of inhibition observed. In addition, the early rapid component was present even at extracellular chromate levels which did not cause significant "autoinhibition."

Because exchangeable intracellular chromate was not demonstrated in these studies, the question may be raised that all the phenomena observed are related to chromate binding to sites on or near the cell surface rather than to a transmembrane flux. We exclude this possibility for the following reasons: $(a)$ over the extracellular chromate concentration range studied, the rate of chromate uptake is constant with time and thus independent of the total amount of chromate associated with the cells. However, the influx rates are a hyperbolic function of the extracellular chromate level. If the uptake kinetics were related to saturation of surface-binding sites, the rate of uptake at high chromate concentrations should fall with time as the number of available binding sites are reduced. (b) A dependence on energy metabolism would be unique for a surface binding; (c) surface binding might be expected to be exothermic while chromate uptake is clearly increased with a rise in temperature; and $(d)$ other studies discussed above suggest that chromate enters the intracellular compartment of a number of cell types and participates in intracellular reactions.

It is likely that chromium is an essential trace element in human physiology; this has recently been reviewed extensively (6). Although chromium is absorbed from the gut as $\mathrm{Cr}$ VI, it appears to be present in blood as Cr III which is considered to be the biologically active state. However, a number of mammalian tissues, including erythrocytes (15) and intestine (16), are impermeable to this ion. This suggests that an important intracellular role for chromium would require that chromium be present in the blood in a form which can readily traverse cellular membranes. The presence of a highly specific transport mechanism for $\mathrm{Cr}$ VI in human leukocytes suggests that Cr VI may be the form in which chromium penetrates the cell membrane and thus Cr VI may have an important physiological function. It is possible that the sensitivities of current methods for the detection of trace amounts of $\mathrm{Cr}$ VI in the blood are inadequate.

\section{ACKNOWLEDGMENTS}

We would like to thank Dr. Clifford S. Patlak for his critical review of this manuscript. The excellent technical assistance of Miss Ada Brooks is gratefully acknowledged.

\section{REFERENCES}

1. Gray, S. J., and K. Sterling. 1950. Determination of circulating red cell volume by radioactive chromium. Science (Washington). 112: 179.

2. Ebaugh, F. G., Jr., C. P. Emerson, and J. F. Ross. 1953. The use of radioactive chromium 51 as an erythrocyte tagging agent for the determination of red cell survival in vivo. J. Clin. Invest. 32: 1260.

3. Rajam, P. C., A. L. Jackson, and S. H. Black. 1958. The intracellular labeling of Ehrlich mouse ascites tumor cells with radiochromate. J. Lab. Clin. Med. 51: 767.

4. Aas, K. A., and F. H. Gardner. 1958. Survival of blood platelets labeled with chromium. J. Clin. Invest. 37: 1257.

5. McCall, M. S., D. A. Sutherland, A. M. Eisentraut, and H. Lanz. 1955. The tagging of leukemic leukocytes with radioactive chromium and measurement of the in vivo cell survival. J. Lab. Clin. Med. 45: 717.

6. Mertz, W. 1969. Chromium occurrence and function in biological systems. Physiol. Rev. 49: 163.

7. Goldman, I. D., N. S. Lichtenstein, and V. T. Oliverio. 1968. Carrier-mediated transport of the folic acid analogue, methotrexate, in the L1210 leukemia cell. J. Biol. Chem. 243: 5007.

8. Pearson, H. A. 1963. The binding of $\mathrm{Cr}^{51}$ to hemoglobin. I. In vitro studies. Blood. 22: 218.

9. Ebaugh, F. G., Jr., A. J. Samuels, P. Mossman, D. Heisterkamp, and P. Dobrowolski. 1962. The interaction of the chromate ion and hemoglobin. Proceedings of the IX Congress, International Society of Hematology. 3: 489.

10. Rajam, P. C., and A. L. Jackson. 1958. Distribution and valence state of radiochromium in intracellularly labeled Ehrlich mouse ascites carcinoma cells. Proc. Soc. Exp. Biol. Med. 99: 210.

11. Ronai, P. M. 1969. The elution of ${ }^{51} \mathrm{Cr}$ from labelled leukocytes-a new theory. Blood. 33: 408.

12. Prins, H. K. 1962 . The binding of ${ }^{51} \mathrm{Cr}$ by human erythrocytes. Vox. Sang. 7: 370.

13. Jandl, J. H., M. S. Greenberg, R. H. Yonemoto, and W. B. Castle. 1956. Clinical determination of the sites of red cell sequestration in hemolytic anemias. J. Clin. Invest. 35: 842 .

14. Koutras, G. A., M. Hattori, A. S. Schneider, F. G. Ebaugh, Jr., and W. N. Valentine. 1964. Studies on chromated erythrocytes. Effect of sodium chromate on erythrocyte glutathione reductase. J. Clin. Invest. 43: 323 .

15. Gray, S. J., and K. Sterling. 1950. The tagging of red cells and plasma proteins with radioactive chromium. J. Clin. Invest. 29: 1604.

16. Donaldson, R. M., Jr., and R. F. Barreras. 1966. Intestinal adsorption of trace quantities of chromium. J. Lab. Clin. Med. 68: 484. 